\title{
The Impact of Supply Chain Management on Financial Performance and Responsibility Accounting: Agribusiness Case from Egypt
}

\author{
Mohammed Ali Wahdan ${ }^{1} \&$ Mohamed Ashraf Emam ${ }^{2}$ \\ ${ }^{1}$ Assistant Professor of Accounting, Accounting and Auditing Department, Faculty of Commerce, Menofia \\ University, Egypt \\ ${ }^{2}$ MSc, MBA, Supply Chain and Quality Manager, Modern Agriculture Co. PICO, Cairo, Egypt \\ Correspondence: Mohamed Ali Wahdan, Faculty of Commerce, Menoufia University, Shebin El-Kom, Menofia, \\ Egypt.
}

Received: February 6, 2017

Accepted: April 1, 2017

Online Published: April 11, 2017

doi:10.5430/afr.v6n2p136

URL: https://doi.org/10.5430/afr.v6n2p136

\begin{abstract}
This paper presents the impact of applying the supply chain management (SCM) on the agribusiness field to optimize productivity and decreasing cost which will have a direct impact on the net income of the organization. The main two research questions are: is there a significant impact of supply chain management on financial performance? and is there a significant relationship between supply chain management and financial performance as well as responsibility accounting? To answer the research questions, data was collected from financial statements of agribusiness case from Egypt and the survey was conducted. The findings of the study indicated that there is a significant impact of supply chain management on financial performance through enhancing the productivity, decreasing the cost and improving profitability. Moreover, applying the efficient supply chain management can improve the use of responsibility accounting through the efficient usage for the budget of the crop.
\end{abstract}

Keywords: Supply chain management, Financial performance, Responsibility accounting, Agribusiness case study, Egypt

\section{Introduction}

Supply chain management (SCM) is defined as a combination of different arrangements. It occurs between various business entities involved in the production, procurement, processing, and marketing of products. The arrangements include aspects of marketing, economics, logistics and organizational behavior" (Brown, 2002). The best companies around the world are discovering a powerful new source of competitive advantages called a supply chain management. It involves all of those integrated activities that convey product to market and create satisfied customers. The supply chain management program integrates themes from manufacturing operations, purchasing, transportation, and physical distribution into a unified program. So, successful supply chain management organizes and incorporates all of these activities into a unified process. It holds and associates all of the partners in the chain. Those partners, in addition to the departments within the organization, include vendors, carriers, third-party companies, and providers of information systems (Zigiaris, 2000; Sweeney, 2007). In last decade, researchers concentrated on supply chain management themes in profit organizations. Research objectives may include adding value, reducing cost, or reducing response time in various parties involved in the manufacturing supply chain (Habib, 2011).

Furthermore, management uses responsibility accounting as a control device. The aim of responsibility accounting is to help management in achieving organizational goals. It is an invaluable support to modern management. It contributes to the firm's management by providing relevant information on a continuous basis" (Fowzia, 2011). Responsibility accounting reports are categorized to different levels of responsibility. They start from lowest to highest level of responsibility in the hierarchy. Performance reports usually reflect the budgeted and actual financial results of the related responsibility centers. Management reporting is divided into two types: responsibility reporting and information reporting. Such reports aim to report and inform the executives of how duties are fulfilled in the areas that the reporter is directly responsible and how to motivate them to improve performance (Mojgan, 2012).

The problem of the research can be represented mainly in huge production volumes coming in very short harvesting window in a Modern Agriculture Company-PICO, a leading Egyptian family owned shareholding company that is 
successfully working in developing agri-projects for over 30 years to produce premium quality fruits and vegetables and exporting its products worldwide with all the high-end retailers in the UK and EU (PICO Agriculture website 2012). PICO grows substantial areas of strawberries, grapes and stone fruits as well as citrus, mangos, avocados, pomegranates, bananas, lychees and leafy vegetables (PICO Agriculture website 2012). PICO meets the international standards targeting the highest qualifications of UK and European supermarkets, which confirm their satisfaction through regular programs and visits as well as accredited certificates such as Global Gap, BRC, Tesco Nurture choice, Field to Fork, ISO 9001, ISO 22000 as well as Ethical Trading Initiative ETI. (PICO Agriculture website 2012). To summarize the research problem, the Company (PICO) produced 3500 tons of table grapes in 2010 and increased up with $15 \%$ to achieve 4000 tons in 2013 . Hence, the season starts mid-May and lasts only for one and half month, until end of June. This makes the management suffers from issues and managerial implications that cannot be under control in the normal conditions. Moreover, the very high costs occurred during the season because of the following problems: (Based on interviews with PICO top and middle management) (1) Restoration of some technical operations due to inefficiency at the first round, (2) Delay in several operations due to mismanagement, (3) Poor communication among different departments, and (4) The poor management planning. All these problems affect directly the net income of the table grapes crop. The authors suggest that applying supply chain management at this point of time can eliminate most of these problems through applying the management techniques that organize executing the operations on the right time with the required specifications end up with better quality at the right cost. Because of above-mentioned problems, efficiency here is translated at the end into net profit.

The advantages of the supply chain management approach are numerous such as: (Roekel, et al., 2002) (1) Reduction of product losses in transportation and storage, (2) Increasing of sales, (3) Dissemination of technology, advanced techniques, capital and knowledge among the chain partners, (4) Better information about the flow of products, markets and technologies, (5) Transparency of the supply chain, (6) Tracking the source, (7) Better control of product safety and quality, and (8) Better share of large investments and risks among partners in the chain.

The objectives of supply chain management are to achieve high levels of customer service in targeted markets/segments and to enhance total supply chain investment and optimize cost. This service/cost approach has long been considered as central to supply chain management. This approach requires companies to have a clear understanding of both issues (services and cost). A customer service requirement sets the specifications for the supply chain. Achieving this level of service at the optimal cost focuses attention on the elimination of non-value adding activities throughout the supply chain (Sweeney, 2002). Chopra and Meindl (2010) defined the success of a supply chain in terms of supply chain profitability. So, the next logistical step is to look for sources of revenue and cost. For any supply chain, there is only source of revenue: the customer.

From the above discussion, the objectives of the current study are to investigate the impact of supply chain management on financial performance and illustrating the relationship between supply chain management and financial performance as well as responsibility accounting. The study shows the impact of supply chain management on the productivity, direct cost, and profitability. The study seeks a great impact on the final net income of the company while the scarcity of studies on the field as well as the application into the agri-business. The main two research questions are, is there a significant impact of supply chain management on financial performance? and is there a significant relationship between supply chain management and financial performance as well as responsibility accounting? To answer the research questions, data was collected from financial statements of the Agribusiness case from Egypt (PICO) and the survey was conducted.

The outline of the paper is as follows. Section two presents the literature review and hypotheses development. Section three introduces research methodology. Section four presents the discussion and results. Section five provides contribution and implications. Section six presents the conclusion and points to future research.

\section{Literature Review and Hypotheses Development}

In this section, the related literature is reviewed and the hypotheses are developed.

\subsection{Supply Chain Management and Financial Performance}

Roekel et al (2002) discussed that market liberalization and increasing consumer demand in Organization for Economic Co-operation and Development (OECD) countries offer attractive opportunities for agricultural exporters from developing countries. Particularly for producers in these countries, collaboration between trade partners has become increasingly important for the success of cross-border trade in the competitive market. Supply chain management is a dominant tool to achieve this collaboration. Through supply chains, producers in developing countries and emerging economies can access market information and knowledge to enhance their value-added 
activities. Some important advantages of supply chain management are: reduction of product losses, increasing of sales, reduction of transaction costs, a better control of product quality and safety and the distribution of technology, capital and knowledge among the chain partners.

In 2002, the study of Brown used case studies of three different agribusinesses to demonstrate the principles of supply chain management and how it is applied. The agribusiness cases demonstrate a practical application of supply chain management that can affect and be applied to farm businesses throughout the world. As conclusion farm businesses, all over the world are entering various agreements with off farm businesses as part of the movement toward increased supply chain management. If the farm business manager is willing to give up some independence to reduce risks and perhaps assure the long-term viability of the farm business, then he/she should become involved in supply chain management.

Trienekens et al. (2003) discussed the innovation through international food supply chain development between developing countries and developed countries. Two case studies on fruit export chains from Africa are analyzed. One case is exporting pineapples from Ghana and the second is exporting table grapes from South Africa. As a conclusion of the study: first, consumer demand is transferred through the supply chain through the quality and safety demand of western retailers. Second, important and great change has been implemented in production systems and use of technology especially in the field of quality and safety. Third, the change in end user demand at the end of the chain affect the production, packing and quality at the beginning of the supply chain. Fourth, the focus in both case studies on the infrastructure and product related improvements.

In 2007, the study of Aramyan et al. aimed at contributing to the development of a Performance Measurement System (PMS) for agri-food supply chains that involves the entire chain (i.e. all stages starting from raw materials to retailers) and includes a comprehensive set of performance indicators. For this purpose, Dutch vegetable supply chains have been chosen as a case study. Results indicate that some Quality Assurance Systems (QAS) requirements are perceived to have a positive impact on some supply chain members' performance, while they are perceived to have a negative impact on other chain members' performance.

In 2008, the study of Jaffee et al. described the methodology for a Rapid Agricultural Supply Chain Risk Assessment (RapAgRisk) developed by the Commodity Risk Management Group (CRMG) of the World Bank. The primary objective of the RapAgRisk is to help decision makers understand the risk exposure of agricultural supply chain participants and to identify improved risk management strategies for selected commodity systems. Based on this typology, the paper examined risk transmission mechanisms across the supply chain and within particular sub-systems. The conceptual framework also dealt with the analysis of risk management practices and vulnerability. The study sets out the steps and sequences required to undertake the RapAgRisk.

Percy (2009) determined the nature of linkages in agribusiness supply chain with the objective of developing a theoretic framework on how collaboration can enhance the competitiveness of multiple linked agribusiness supply chains in South Africa. As a conclusion of the study the drives of supply chain management phenomenon increased demand for better and faster customer service, globalization of business and competition, availability of information technology to facilitate information exchange, adaptive forms of Relationship Management. The growth of these factors has helped organization realize the need to manage their supply chains holistically to achieve strategic advantages.

In 2010, the study of Trivedi threw light on the financial condition and financial performance of Gujarat State Road Transport Corporation (GSRTC) over a given period. The main motto behind this study is to contribute in this direction and create value for all stakeholders, public, employees, vendors, state government and fund providers.

Trienekens (2011) introduced value chain analysis in terms of its theoretical background and its application to value chains in developing countries. As a conclusion of the study for a balanced analysis of value chains, the study proposed three key elements: (1) network structure, of horizontal and (vertical) market channel relationships; (2) value added, as related to the key competitive aim of any business chain; and (3) governance, covering organizational arrangements between value chain actors.

In 2011, the study of Bhunia et al. aimed to identify the financial strengths and weaknesses of the Indian public sector pharmaceutical enterprises by properly establishing relationships between the items of the balance sheet and profit and loss account. The study covers two public sectors; drug and pharmaceutical enterprises listed. The main objectives of the study are to make a study on the overall financial performance of selected public sector drug \& pharmaceutical enterprises in India. More specifically, it seeks to dwell upon mainly (i) to assess the short-term and long-term solvency, (ii) to assess the liquidity and profitability position and trend, (iii) to know the efficiency of 
financial operations and (iv) to analyze the factors determining the behavior of liquidity and profitability. The findings of the study indicated that the liquidity position, long-term solvency and financial stability ratios were different from one enterprise to another, reflecting the ability of the enterprises to pay short-term obligations on due dates and the extent of their reliance on external funds.

In 2011, the study of Chisholm explored the commercial potential of indigenous African crops and models a supply chain that integrates small-scale cooperative farms with large-scale cultivation for agricultural export. The research addresses the existing systems' deficiencies while analyzing the prospect for global supply chain expansion for food products sourced from Africa to China. The model seeks to overcome current challenges and to enable competitive advantage, as well as infrastructure and economic development.

Alam \& Faridi, (2011) discussed not only witnessing a high economic volatility, economic turbulence, recession but also an unstable customer demand, complexities in production, un-anticipated delays in the chain of processes. This has made supply chain management under high pressure to be more responsive, efficient, customer oriented, and innovative, which helps in reducing the cost. The paper is a brief beginning to know how conflicts in supply chain management occur, how they are to be resolved and how to minimize these conflicts which indeed is a cost of delay, funds, quality, wastages, and unhealthy environment etc.

Khan (2012) demonstrated that improving supply chain is beneficial both for the producer and final consumer as producers would get remunerative price for his product and consumer would be benefitted from the lower price. As a conclusion of the study increasing efficiency of supply chain could help in bringing food inflation down and increase the efficiency of our food markets and make our agriculture sector sustainable and viable.

In 2013, the study of Demir pioneers' organic marketplace from the perspectives of supply chain management paying special attention to the network structure and critical activities. Special inventory handling approaches such as cross docking are applied and transportation is a major issue. As a conclusion of the study: First, activities for successful supply chain management such as cooperation, integrated behavior and mutually sharing risks and rewards take place naturally. Second, the price premium, although partially justified, appears to be an impediment to the widespread consumption of organic products. In addition, due to high prices, shoppers at the organic market are mostly people with high-income levels and the organic market is in danger of becoming a place for elites.

In 2016, Abunar and Zerban argued that the application of information technology is prominent in the improvement of the supply chain. This study aimed to explore the relationship between retailers and suppliers in Saudi Arabia market and their sharing of information regarding stock levels to improve supply chain management. The findings of the study indicated that the integration of information in processing orders from supermarkets to suppliers in going to be investigated in order to improve supply chain management.

By reviewing the literature, some studies focused on improving the agri-products quality with cutting down costs through applying supply chain management because of the high increase in global market standards. While other studies dealt with the relationship between supply chain management and the financial performance. This increase in global market standards of the fresh products over time resulted in the production processes that become more challenging. Some other studies highlighted the importance of using the technology in production and logistics processes. The objectives of these studies focused on producing and/or delivering high quality agriculture products to the consumer with competitive prices. While other studies aimed to enhance the efficiency and effectiveness of the agri-business and other businesses performance to develop the competitive edge through applying the supply chain management. The improvement of supply chain management processes starts from the suppliers, passes through production processes, and the marketing and logistics activities as well as the customer feedback.

The current study focuses on the impact of applying supply chain management on financial performance in terms of productivity, direct costs, and profitability to increase the efficiency of the company operations through improving product quality with cutting down costs to increase the net profit of the organization. Therefore, the following four hypotheses are stated:

H1 : "There is no significant impact of supply chain management on productivity"

H2 : "There is no significant impact of supply chain management on direct costs"

H3 : "There is no significant impact of supply chain management on profitability"

H4 : "There is no significant relationship between supply chain management and financial performance" 


\subsection{Supply Chain Management and Responsibility Accounting}

In 2000, the study of Jones \& Thompson demonstrated the information/transaction costs make it necessary to decentralize some decision rights in organizations and in the economy. Capitalist economies solve these control problems through the institution of alienable decision rights. But because organizations suppress the alienability of decision rights, they must devise substitute mechanisms that perform those functions. Three functions are critical: (1) allocating decision rights among agents in the organization, (2) measuring and evaluating performance, and (3) rewarding and punishing individuals for their performance.

In 2012, the study of Mojgan discussed the centralized operations in organizations become more complicated in case of business development, the need to delegate authorities and responsibilities will depend on the size of the business. In a decentralized business organization, directors are responsible for planning and controlling the corporate operation. The responsibility accounting system is designed to report and accumulate costs by individual levels of responsibility. As a conclusion, responsibility accounting is a method different from piling up costs and puts more emphasis on evaluating operations than costing production, it can cover an overall scheme consisting of all aspects of production, marketing, administrative and financial affairs within an organization by taking advantage of "planning" and "controlling" techniques. In fact, it can identify each manager with a responsibility to achieve his attainable objectives.

In 2012, the study of Al-Bawab aimed to highlight the importance of accounting responsibility in Yemeni banks. The study found several results summarized as follows: First, there are positions of responsibility in the different administrative levels in the banks of Yemen. Second, there are measures of financial performance to evaluate the performance in the Yemeni banks. Third, there are measures of non-financial performance to evaluate the performance in the Yemenian banks. Fourth, there is no relationship between the identification of positions of responsibility in the different administrative levels and the use of financial measures to evaluate performance. Fifth, there is a relationship between the identification of positions of responsibility in the different administrative levels and non-financial metrics used to evaluate the performance. Finally, there is no relationship between the use of measures of financial performance and the use of nonfinancial measures to evaluate performance.

In 2012, the study of Marius et al. demonstrated that the goals of an economic entity are very diverse; generally, it will desire to maximize its results, while trying to pursue some goals characterizing different aspects of the activities it carries out. In order to be able to attain their goals, organizations manage diverse structures, entrusting the tasks to be carried out to different responsibility centers. During a period in which managerial calculation systems and economic applications are becoming commonplace in organizations, cost calculation using modern systems shapes the overall corporate management but also the management of each section or workshop, contributing to the increase of the responsibility of each cost-generating place.

In 2013, the study of Tiwari discussed management and accounting of green supply chain is a recent and important concept. Their contributions are organized around five key issues in the green chain: concepts of measuring performance; empirical research in measuring costs, benefits and risk; modeling; value of information; and governance and performance. Globalization of supply chains complicates the chain governance. As a conclusion of the study green Supply Chain Management (SCM) is the management of a network of interconnected businesses involved in the ultimate provision of green-product and green-service packages required by end customers. Accounting of green-food Supply chain is a recent and most important concept.

Shabani et al. (2013) had shown that firms are more successful when they focus on their customers' needs. Although some empirical studies have investigated the relationship between Product-related attributes of customers and financial performance. They have failed to show the mechanism by which Product-related attributes of customers promotes financial performance. This study explored how Product-related attributes of customers' financial performance. Despite ongoing debate regarding the specific dimensions of the customer relationship orientation construct, the link with organizational performance is almost universally recognized. The findings suggest that financial service managers could consider treating consumers as partners in their provision of existing services or their quest to develop successful new services.

Prior studies focused on the role of responsibility accounting in supply chain management. The current study highlights the role of responsibility accounting as a monitoring and controlling system. In addition, this study will test the association between the supply chain management and the responsibility accounting. Therefore, the fifth hypothesis is stated as follows:

H5 : "There is no significant relationship between supply chain management and responsibility accounting" 


\section{Research Methodology}

The research is conducted as a case study in the Modern Agriculture Company PICO for the table grapes sector. The table Grapes is considered to the second strategic crop for the company after the banana. The crop represents around $16 \%$ of the company turnover in 2008/2009 and around $20 \%$ of the yearly turnover in 2013/2014.

The required data has been collected from primary sources and secondary sources, and this can be illustrated as follows: Primary data collected via Surveys as a direct and structured questionnaire designed and distributed to the wide range of employees working in the field of the study including all hierarchy levels started from the managing director. The questionnaire is a 5 Likert-scale and contains four parts, first part includes 14 items about the existence of supply chain management which includes demand management, convert to automation, using technology, innovation, as well as inventory management. Second part is 8 items regarding the efficiency of agricultural operations which explains the lead time decrease, optimum use of labors, using new techniques as well as proper training and awareness execution. Third part consists of 8 items regarding the direct costs of agriculture operations which measure the effect of new technology, efficient use of labors, precious planning and training on direct cost of the agriculture operations. Fourth part includes 5 items for responsibility accounting which monitors the company performance against budget as well as controls the financial variances.

Secondary data presented in income statements for the table grapes project of PICO Modern Agriculture Company are provided through the financial department started from financial year 2008/2009 up to 2013/2014. From the income statements, the productivity per acre over the given period, direct costs per acre as well as profit per acre for the same period.

The questionnaire participants are shown in table 1. The number of distributed questionnaires was sixty-seven. Total number of received questionnaires was sixty-one; two of them are not valid, hence total valid questionnaires for analysis were fifty-nine questionnaires. The fifty-nine questionnaires analyzed from the 67 distributed represents $88 \%$ response rate. This rate is considered to be acceptable to be used in the statistical data analysis. It is shown that all participants in the survey are directly related to the field of table grapes; starting from the new engineers newly hired and responsible for one piece of cultivated land up to the managing director of the company.

Table 1. questionnaires distributed/returned and its classification

\begin{tabular}{llllll}
\hline Descriptors & Distributed & Returned & Invalid & Valid & Percentage \% \\
\hline Agricultural Engineers & 29 & 26 & 1 & 25 & $42.4 \%$ \\
\hline Accountants & 9 & 7 & & 7 & $11.9 \%$ \\
\hline Financial Managers & 4 & 4 & & 4 & $6.8 \%$ \\
\hline Sector Managers & 16 & 15 & 1 & 14 & $23.7 \%$ \\
\hline Farm Managers & 3 & 3 & & 3 & $5.1 \%$ \\
\hline Department Managers & 5 & 5 & & 5 & $8.5 \%$ \\
\hline Managing Director & 1 & 1 & & 1 & $1.7 \%$ \\
\hline Total & $\mathbf{6 7}$ & $\mathbf{6 1}$ & $\mathbf{2}$ & $\mathbf{5 9}$ & $\mathbf{1 0 0 \%}$ \\
\hline
\end{tabular}

Source: statistical results

Table 2. Frequencies and percentages of the education level of the questionnaire participants

\begin{tabular}{lll}
\hline Descriptors & Frequency & Percent \\
\hline Bachelor & 53 & $89.8 \%$ \\
\hline Masters & 5 & $8.5 \%$ \\
\hline PhD & 1 & $1.7 \%$ \\
\hline Total & $\mathbf{5 9}$ & $\mathbf{1 0 0 \%}$ \\
\hline
\end{tabular}

Source: statistical results

In table 2 , it is shown that most of the participants $(89.8 \%$ ) are holding a bachelor degree and $8.5 \%$ only are holing masters' degree, however, only $1.7 \%$ hold $\mathrm{PhD}$ which reflects that the participants have enough expertise and awareness in the field of the study. The education level refers that all participants are qualified enough to participate in the survey and submit their point of view. 
Table 3. Frequencies and percentages of the experience of the questionnaire participants

\begin{tabular}{lll}
\hline Descriptors & Frequency & Percent \\
\hline Less than 5 & 5 & $8.5 \%$ \\
\hline From 6 to 10 & 13 & $22.0 \%$ \\
\hline From 11 to 15 & 15 & $25.4 \%$ \\
\hline From 16 to 20 & 7 & $11.9 \%$ \\
\hline More than 20 & 19 & $32.2 \%$ \\
\hline Total & $\mathbf{5 9}$ & $\mathbf{1 0 0 \%}$ \\
\hline
\end{tabular}

Source: statistical results

In table 3 , it is shown that more than $32 \%$ of participants are more than 20 years' experience within the field and $37.3 \%$ of participants have experience between 11 and 20 years which reflect that the participants have enough experience and awareness about the field of the study. The participants have enough experience to understand and fill the required questionnaire.

\section{Research variables}

The variables of the study are one independent variable, supply chain management, and four dependent variables; profitability, direct costs, profitability and responsibility accounting. This research is measuring the impact of supply chain management on financial performance (productivity, direct costs, and profitability), and the relationship between the supply chain management and responsibility accounting as shown in figure 1 . The financial performance can be measured through the direct costs and efficiency of agriculture technical operations.

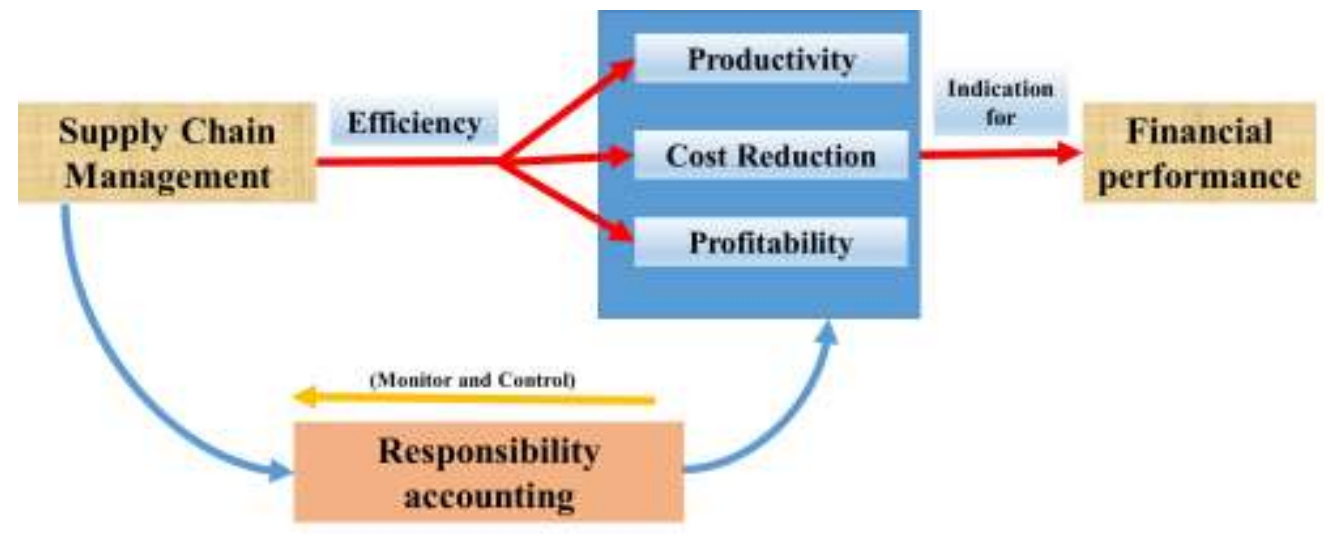

Figure 1. Linking SCM with financial performance and responsibility accounting

The figure links the study variables together. It shows how supply chain management has an impact on the financial performance. This is measured by the indicators which are productivity, costs reduction and profitability. It also shows the monitoring and controlling role of responsibility accounting.

\section{Statistical techniques}

Multiple statistics techniques have been used in the study as follows (Bashir, 2008): (1) Reliability and Validity test (Alpha Correlation Coefficient), (2) Regression test, and (3) Spearman Correlation Coefficient.

\section{Discussion and Results}

To measure the reliability and validity tests. Coefficient alpha is the most popular coefficient reported to support the reliability of a scale. Coefficient alpha is easy to interpret and refers to the degree coefficient alpha approaches 1.0; a scale demonstrates greater internal consistency. Table 4 highlights the coefficient of reliability and validity for each variable. It shows the measures of all variables included in the four parties of the questionnaire that consists of thirty-five items that describe the main elements for SCM, financial performance and responsibility accounting. 
Table 4. Alpha coefficient and the validity for each variable

\begin{tabular}{|c|c|c|c|}
\hline Descriptor & $\begin{array}{l}\text { No. } \\
\text { of items }\end{array}$ & $\begin{array}{l}\text { Alpha } \\
\text { coefficient }\end{array}$ & Validity \\
\hline $\begin{array}{l}\text { Part one (S) } \\
\text { Supply chain management }\end{array}$ & 14 & .838 & .943 \\
\hline $\begin{array}{l}\text { Part two (E) } \\
\text { Efficiency of agriculture } \\
\text { operations }\end{array}$ & 8 & .740 & .860 \\
\hline $\begin{array}{l}\text { Part three }(\mathrm{C}) \\
\begin{array}{l}\text { Direct costs of agriculture } \\
\text { operations }\end{array}\end{array}$ & 8 & .813 & .902 \\
\hline $\begin{array}{l}\text { Part four }(\mathrm{R}) \\
\text { Responsibility accounting }\end{array}$ & 5 & .736 & .858 \\
\hline Overall measure & 35 & .927 & .963 \\
\hline
\end{tabular}

Source: statistical results

The results in table 4 illustrate that the alpha coefficient of supply chain management equals .838 and the validity coefficient equals .943. In addition, the alpha coefficient of efficiency of agriculture operations equals .740 and the validity coefficient equals .860 . Furthermore, the alpha coefficient of the direct costs of agriculture operations equals .813 and the validity coefficient equals .902 . Moreover, the alpha coefficient of responsibility accounting equals .736 and the validity coefficient equals .858 . Finally, the overall measure of alpha coefficient equals .927 and the validity coefficient equals .963 (which is considered high).

As a conclusion from table 4, the coefficients of Cronbach alpha and validity coefficients for all measures for all variables are relatively high. So, we can generalize the results of the case study to the similar companies.

\section{Hypotheses testing}

\section{H1: There is no significant impact of supply chain management on productivity.}

Table 5 shows that the difference between the means of the total production per acre for the available period before and after applying supply chain management which is $45 \%$ increase in the production after applying supply chain management in the table grapes sector in the company.

Table 5. Productivity per acre statistical data

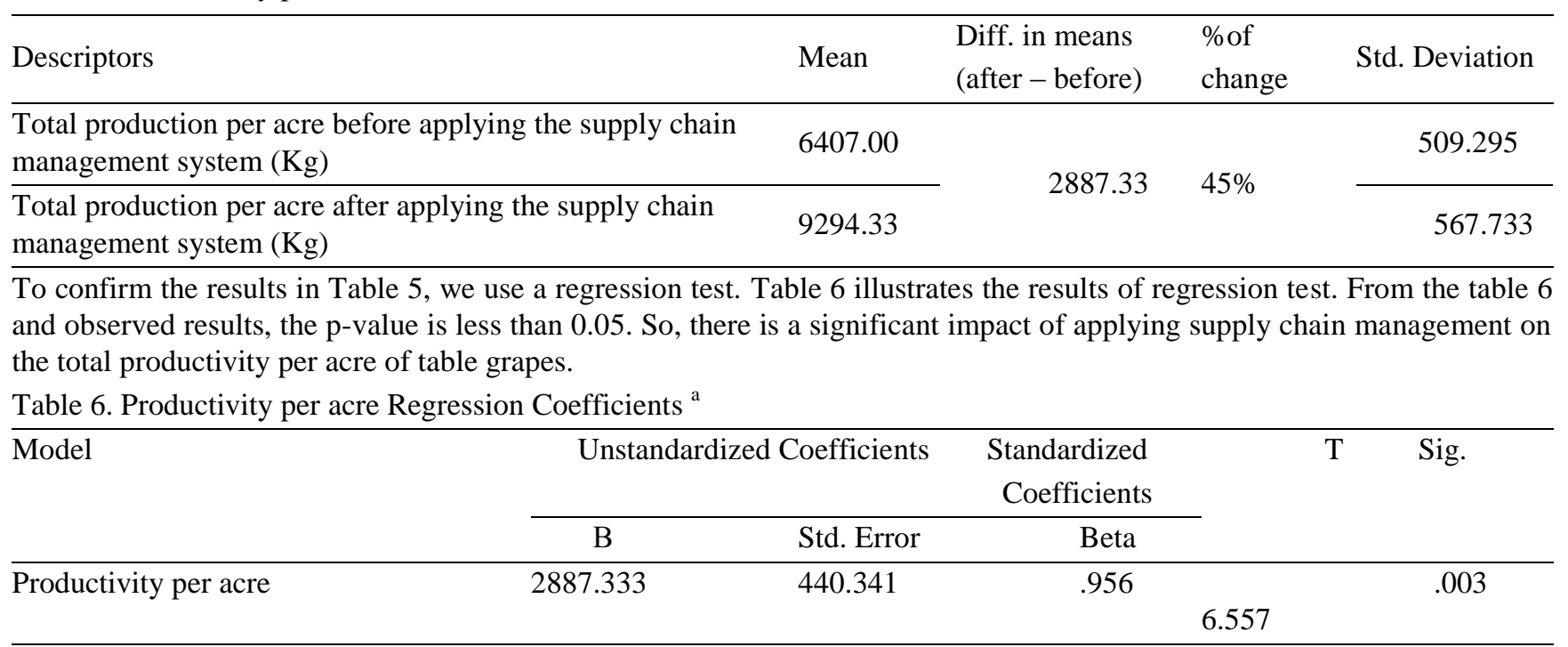

a. Dependent Variable: Total productivity per acre

Source: statistical results 


$$
\text { Regression model: } y_{1}=a+b x
$$

While $\mathrm{y}_{1}$ is the total productivity and $\mathrm{x}$ is the supply chain management. $\mathrm{X}$ has two values, 0 for the three years before apply the SCM and 1 for the three years after applying the SCM.

Here, due to the total productivity consists of export market productivity and local market production $\left(\mathrm{y}_{1}=y_{l a}+\right.$ $y_{1 b}$ ), so we can test the impact of supply chain management on both export market productivity and local market production as follows. Tables 7 and 8 illustrate the test results of export market productivity.

Table 7. Export market productivity statistical data

\begin{tabular}{|c|c|c|c|c|}
\hline Descriptors & Mean & $\begin{array}{l}\text { Diff. in means } \\
\text { (after - before) }\end{array}$ & $\%$ of change & Std. Deviation \\
\hline $\begin{array}{l}\text { Export production per acre before applying the } \\
\text { supply chain management system }(\mathrm{Kg})\end{array}$ & 4518.33 & \multirow{2}{*}{2311.34} & \multirow{2}{*}{$51 \%$} & 171.646 \\
\hline $\begin{array}{l}\text { Export production per acre after applying the } \\
\text { supply chain management system }(\mathrm{Kg})\end{array}$ & 6829.67 & & & 591.545 \\
\hline
\end{tabular}

Table 7 illustrates that the difference between the means of the export production volumes per acre for the available period before applying supply chain management is $51 \%$ increase in the export production volumes after applying supply chain management in the table grapes sector in the company.

Table 8. Export market productivity Regression Coefficients

\begin{tabular}{lcccccr}
\hline Model & \multicolumn{2}{c}{ Unstandardized Coefficients } & Standardized Coefficients & T & Sig. \\
\cline { 2 - 5 } & $\mathrm{B}$ & Std. Error & & \\
\hline Export production per acre & 2311.333 & 355.616 & .956 & 6.500 & .003 \\
\hline
\end{tabular}

Source: statistical results

\section{Regression model: $y_{1 a}=a+b x$}

While $\mathrm{y}_{1 \mathrm{a}}$ is the export market productivity and $\mathrm{x}$ is the supply chain management. $\mathrm{X}$ has two values, 0 for the three years before apply the SCM and 1 for the three years after applying the SCM.

Table 8 shows the p-value is less than 0.05 . So, there is a significant impact of supply chain management on export production volumes per acre. As a result, applying supply chain management can increase the export productivity percentage from the overall production.

Tables 9 and 10 illustrate the test results of local market productivity.

Table 9. Local market productivity statistical data

\begin{tabular}{|c|c|c|c|c|}
\hline Descriptors & Mean & $\begin{array}{l}\text { Diff. in means } \\
\text { (after - before) }\end{array}$ & $\begin{array}{l}\% \text { of } \\
\text { change }\end{array}$ & Std. Deviation \\
\hline $\begin{array}{l}\text { Local production per acre before applying the } \\
\text { supply chain management system }(\mathrm{Kg})\end{array}$ & 1888.67 & \multirow{2}{*}{576.33} & \multirow{2}{*}{$31 \%$} & 520.394 \\
\hline $\begin{array}{l}\text { Local production per acre after applying the } \\
\text { supply chain management system }(\mathrm{Kg})\end{array}$ & 2465 & & & 196.054 \\
\hline
\end{tabular}

Table 9 shows that the difference between the means of the local production volumes per acre for the available period before applying supply chain management is $31 \%$ increase in the local production after applying the supply chain management however there is no significant difference.

Table 10. Local market productivity Regression Coefficients

\begin{tabular}{lccccc}
\hline Model & \multicolumn{2}{c}{ Unstandardized Coefficients } & Standardized Coefficients & \multirow{2}{*}{ T } & Sig. \\
\cline { 2 - 5 } & $\mathrm{B}$ & Std. Error & & Beta & \\
\hline Local production per acre & 576.333 & 321.065 & .668 & 1.795 & .147 \\
\hline
\end{tabular}

Source: statistical results 


\section{Regression model: $y_{1 b}=a+b x$}

While $\mathrm{y}_{1 \mathrm{~b}}$ is the local market productivity and $\mathrm{x}$ is the supply chain management. $\mathrm{X}$ has two values, 0 for the three years before apply the SCM and 1 for the three years after applying the SCM.

Table 10 illustrates that the p-value is greater than 0.05 . So, there is no significant impact of supply chain management on local market productivity. As a result, applying supply chain management may not increase the local productivity percentage from the overall production.

Therefore, the first hypothesis is rejected, which means that the impact of supply chain management is significant for the total productivity of the table grapes in particular the export market production, which requires higher quality specifications. As a result, supply chain management can increase the total productivity per acre and enhance the quality of production under the same technical treatments while all other variables are constant.

H2: There is no significant impact of supply chain management on direct costs.

Tables 11 and 12 illustrate the test results of direct costs.

Table 11. Direct costs statistical data

\begin{tabular}{lccrr}
\hline Descriptors & Mean & $\begin{array}{c}\text { Diff. in means } \\
\text { (after - before) }\end{array}$ & $\begin{array}{c}\% \text { of } \\
\text { change }\end{array}$ & $\begin{array}{r}\text { Std. } \\
\text { Deviation }\end{array}$ \\
\hline $\begin{array}{l}\text { Direct costs per acre before applying the supply } \\
\text { chain management system (L.E.) }\end{array}$ & 37516.00 & & $(11 \%)$ & 1641.217 \\
$\begin{array}{l}\text { Direct costs per acre after applying the supply } \\
\text { chain management system (L.E.) }\end{array}$ & 33428.67 & $(4087.33)$ & & 97.079 \\
\hline
\end{tabular}

Table 11 shows that the difference in means of the direct costs per acre for the available period before applying supply chain management is $11 \%$ decrease in the direct costs after applying supply chain management in the table grapes sector in the company.

Table 12. Direct costs Regression Coefficients ${ }^{\text {a }}$

\begin{tabular}{lllcll}
\hline Model & \multicolumn{2}{c}{ Unstandardized Coefficients } & Standardized Coefficients & \multirow{2}{*}{ T } & \multirow{2}{*}{ Sig. } \\
\cline { 2 - 5 } & B & Std. Error & Beta & & \\
\hline Direct costs & -4087.333 & 949.213 & -.907 & -4.306 & .013
\end{tabular}

a. Dependent Variable: Direct Costs per acre

Source: statistical results

$$
\text { Regression model: } y_{2}=a+b x
$$

While $\mathrm{y}_{2}$ is the direct costs and $\mathrm{x}$ is the supply chain management. $\mathrm{x}$ has two values, 0 for the three years before apply the SCM and 1 for the three years after applying the SCM.

In addition to the above results, there is a significant impact of supply chain management on the direct costs per acre. From table 12, the p-value is less than 0.05 . Therefore, the second hypothesis is rejected. So, there is a significant impact of supply chain management on direct costs. As a result, applying supply chain management can save costs through using new technologies, enhancing the efficiency and effectiveness of technical operations as well as rationalizing the use of raw materials.

H3: There is no significant impact of supply chain management on profitability.

Tables 13 and 14 illustrate the test results of profitability.

Table 13. Gross operating profit statistical data

\begin{tabular}{|c|c|c|c|c|}
\hline Descriptors & Mean & $\begin{array}{l}\text { Diff. in means } \\
\text { (after- before) }\end{array}$ & $\begin{array}{c}\% \text { of } \\
\text { change }\end{array}$ & Std. Deviation \\
\hline $\begin{array}{l}\text { Gross operating profit per acre before applying the } \\
\text { supply chain management system (L.E.) }\end{array}$ & 19881.33 & \multirow{2}{*}{5434.67} & \multirow{2}{*}{$27 \%$} & 1530.801 \\
\hline $\begin{array}{l}\text { Gross operating profit per acre after applying the } \\
\text { supply chain management system (L.E.) }\end{array}$ & 25316.00 & & & 2562.659 \\
\hline
\end{tabular}


The table 13 illustrates the difference in means of the gross operating profit (GOP) per acre for the available period before applying supply chain management, which represents $27 \%$ increase in the gross operating profit after applying supply chain management in the table grapes sector in the company.

Table 14. GOP Regression Coefficients ${ }^{\text {a }}$

\begin{tabular}{lccccc}
\hline Model & \multicolumn{2}{l}{ Unstandardized Coefficients } & Standardized Coefficients & \multirow{2}{*}{ T } & Sig. \\
\cline { 2 - 4 } & $\mathrm{B}$ & Std. Error & Beta & & \\
\hline GOP per acre & 5434.667 & 1723.424 & .844 & 3.153 & .034 \\
\hline
\end{tabular}

a. Dependent Variable: GOP per acre

Source: statistical results

$$
\text { Regression model: } y_{3}=a+b x
$$

While $\mathrm{y}_{3}$ is the gross operating profit and $\mathrm{x}$ is the supply chain management. $\mathrm{x}$ has two values, 0 for the three years before apply the SCM and 1 for the three years after applying the SCM.

Also, there is a significant impact of supply chain management on gross operating profit. From table 14, the p-value is less than 0.05 . Therefore, the third hypothesis is rejected. So, there is a significant impact of supply chain management on profitability.

H4: There is no significant relationship between supply chain management and financial performance.

This hypothesis tends to investigate the correlation between supply chain management and financial performance represented in the efficiency of agriculture technical operations and direct costs. To test the hypotheses, Spearman correlation test is used to calculate the correlation coefficient between supply chain management and efficiency of agriculture technical operations as well as the correlation coefficient between supply chain management and direct costs.

Table 15 illustrates the results of the correlation coefficient.

Table 15. Study Correlations matrix

\begin{tabular}{lll}
\hline & & Supply Chain Management \\
\cline { 2 - 3 } Spearman's rho & Efficiency of agricultural operations & .000 \\
\cline { 2 - 3 } & Direct costs & $.681^{* *}$ \\
\cline { 2 - 3 } & Responsibility Accounting & $.690^{* *}$ \\
\hline \multirow{2}{*}{ **. Correlation is significant at the 0.01 level (2-tailed). } & $.592^{* *}$ \\
\hline
\end{tabular}

Source: statistical results

The previous hypothesis tends to investigate the correlation coefficient between supply chain management and financial performance (efficiency of agriculture technical operations and direct costs). From the correlation matrix stated in table 15, the supply chain management and efficiency of agricultural technical operations are significantly correlated (0.681), which means the relationship is strongly and positively correlated.

Moreover, from the correlation matrix stated in table 15, the correlation between supply chain management and direct costs is 0.690 , which means that the relationship is strongly and positively correlated.

Based upon these results, the fourth hypothesis is rejected. Therefore, there is significant relationship between supply chain management and financial performance.

\section{H5: There is no significant relationship between supply chain management and responsibility accounting.}

The hypothesis tends to investigate the correlation coefficient between supply chain management and responsibility accounting. From the correlation matrix stated in table 15, the correlation between supply chain management and responsibility accounting is 0.592 , which means that the correlation relationship between the supply chain management and responsibility accounting is moderately and positively correlated.

Based upon these results, the fifth hypothesis is rejected. Therefore, there is significant relationship between supply chain management and responsibility accounting. As a result, applying supply chain management can improve the 
use of responsibility accounting which leads to the efficient use of the budget and better control over the direct costs variances.

\section{Contribution and Implications}

The paper makes a number of timely contributions to the extant literature and has policy implications for future agri-business in Egypt. First, it complements and extends the literature on the impact of supply chain management on financial performance in terms of productivity, cost reduction and profitability. Second, it is the first study to provide empirical evidence about the impact of supply chain management on financial performance and responsibility accounting in developing countries (in particular in Egypt). Third, applying the supply chain management to the agri-business in Egypt is a new trend. It becomes an essential requirement after the global market strengths on the prices due to the economic problems worldwide. The market requires very high quality; at the same time the competition makes the price always slopes down over the last years. Most of developed countries and few of developing countries have already applied the supply chain management into the agri-business. The supply chain management in Egyptian agri-business sector is under study from most of the Egyptian large producers/exporters even some of them already started to launch the project on the ground. The agri-business supply chain management projects have been executed in the developing and developed countries can be useful for the Egyptian companies to use as a guide in the way of implementation, taking into consideration the factors that can be changed. Fourth, the contribution of applying the proper supply chain should be beneficiary for all the parties of the supply chain as well as the society. The proper supply chain will result in social benefits. Social benefits can be represented in producing safe products for human consumption compatible with EU MRL standards, increasing the level of knowledge to the workers as well as employees through the training and applying new systems, also reducing the pollution waste as a matter of efficiency. Fifth, on the other hand, the tangible increase in net profits (economic benefits) due to efficiency and cutting down costs will positively affect the income levels of the workers and employees as well as the standard of living. Finally, the contribution to the investment will be reflected on the infrastructure of the company and the information technology systems used which are playing an essential role of the supply chain. The high level of knowledge provided to workers and employees to cope with the new management systems will be definitely reflected to the company performance in terms of efficiency and effectiveness as well as the productivity per capital.

\section{Conclusion, Limitations and Future Research}

This study presents the impact of applying the supply chain management on financial performance and responsibility accounting. The main two research questions examined in this paper are: is there a significant impact of supply chain management on financial performance? and is there a significant relationship between supply chain management and financial performance as well as responsibility accounting? To answer the research questions, data was collected from financial statements of the Agribusiness case from Egypt (PICO) and from a survey. The findings of the study indicated that applying the supply chain management can increase the total productivity per acre under the same technical treatments while all other variables are constant. Moreover, increasing the productivity can be through increasing the export percentage which will gain better income due to the return with foreign currencies through enhancing the product quality and increasing the volumes with the higher class quality. As a result, applying the supply chain management improves the quality of the production to be sold for high-end retailer that can generate higher values, which will have a direct effect on the net profit.

Furthermore, increasing the total productivity per acre leads to decreasing the cost and eliminating the waste. All these results lead to increasing the profitability of the project. So we can conclude that, there is a significant impact of supply chain management on productivity, especially for export market, and decreasing the costs as well as increasing the total productivity. In addition, applying the supply chain management works on cutting down the direct cost associated through the efficiency and effectiveness. Supply chain management can have a great effect on the financial performance of the company through improving revenues and rationalizing the direct costs which significantly will increase the net income as well as boost the company return on investments. Applying the efficient supply chain management can improve the use of responsibility accounting through the efficient usage for the budget for the crop. Precise planning can lead to avoid any cash flow implications as well as cost variances.

There is a limitation to generalize the study results due to we depend on one case study from Egypt, except for the other companies working under the same conditions and possibilities.

Finally, we can recommend that spread the application of supply chain management to other agri-business crops, which can work under the same conditions of table grapes. In addition, the application of the efficient supply chain management to all processes starting from the reception of raw materials until the shipping of the finished product. 
The study of more complicated supply chain that includes the suppliers as well as the customer feedback can be studied in the future in addition to the study of supply chain for other crops that can suffer from different natural conditions, which will definitely affect the entire supply chain. Moreover, the future research can study of the impact of Enterprise Resources Planning (ERP) systems on the supply chain management to improve the agribusiness financial performance.

\section{Acknowledgement}

We gratefully acknowledge the helpful comments of the editor and both anonymous reviewers.

\section{References}

Abunar S.M. \& Zerban, A.M. (2016). Enhancing Accounting Information Systems to Facilitate Supply Chain Management between Supermarkets/Suppliers: The case of Saudi Arabia, Journal of Accounting \& Marketing, $5(2), 1-7$.

Alam T., \& Faridi M. (2011). Conflicts in Supply Chain Management. VSRD international Journal of Business and Management Research, 1(10), 648-654.

Al-Bawab, A. A. (2012). Impact of Decentralization and Responsibility Accounting in Performance Evaluation for The Decentralized Entities at the Yemenian Banks (An Empirical study). Interdisciplinary Journal of Contemporary Research in Business, 3(11), 611-626.

Aramyan, L., Lansink, A.O., Van der Vorst, J., \& Van Kooten, O. (2007). Performance Measurement in Agri-Food Supply Chains: A Case Study. Supply Chain Management: An International Journal, 12(4), 304-315. https://doi.org/10.1108/13598540710759826

Bashir, Muhammad. (2008). Reliability and Validity of Qualitative and Operational Research Paradigm. Pakistan Journal of Statistics and Operation Research, 4(1), 35-35. https://doi.org/10.18187/pjsor.v4i1.59

Bhunia A., Mukhuti S. S. \& Roy. G. S. (2011). "Financial Performance Analysis-A Case Study." Current Research Journal of Social Sciences, 3(3), 269-275.

Brown, W. J. (2002). Agribusiness Cases in Supply Chain Management. 13th International farm Management Congress. Wageningen, The Netherlands.

Chisholm, L. M. (2011). Reinventing Africa into a Global Supplier of Food Goods: An Analysis of Agri-business Development, Sustainability, Supply Chain Integration and Export in Developing Economies. University of California, USA Masters of Business Administration in Management.

Chopra, S. \& Meindl, P. (2010). Supply Chain Management Strategy, Planning and Operation, Fourth Edition, Pearson Education, Inc., Prentice Hall, New Jersey,

Demir, A. Y. (2013). Supply Chain Management Practices in an Alternative Food Network: The First Organic Marketplace in Turkey. International Journal of business and social science, 4(9), 179-187.

Fowzia, R. (2011). Use of Responsibility Accounting and Measure the Satisfaction Levels of Service Organizations in Bangladesh. International Review of Business Research Papers, 7(5), 53-67.

Habib, M. (2011). Supply Chain Management (SCM): Theory and Evolution, Supply Chain Management Applications and Simulations, Prof. Dr. Md. Mamun Habib (Ed.), ISBN:978-953-307250-0,InTech, Available at:

http://www.intechopen.com/books /supply-chain-managementapplications-and-simulations/supply-chain-management-scm-theory-and-evolution.

Jaffee S., Paul S., \& Colin A. (2008). Rapid Agriculture Supply Chain Risk Assessment, Conceptual Framework and Guidelines for Application. Agriculture and Rural Development Discussion Paper 47 (The world bank).

Jones L.R., \& Thompson F. (2000). Responsibility Budgeting and Accounting. International Public Management Journal, 3, 205-227. https://doi.org/10.1016/S1096-7494(00)00036-2

Khan, H R. (2012). Food Inflation and Agricultural Supply Chain Management. 16th Conference of Globoil India, Mumbai (BIS central bankers' speeches).

Marius C. D., Denisa C. M. \& Florina B. I. (2012). Managerial Accounting a Source of Information for an Efficient. Procedia - Social and Behavioral Sciences, 62, 521 - 525. https://doi.org/10.1016/j.sbspro.2012.09.085 
Mojgan, S. (2012). Examining the Role of Responsibility Accounting in Organizational Structure. American Academic \& Scholarly Research Journal, 4(5). Available at: http://www.aasrc.org/aasrj, accessed on Jan $4^{\text {th }}$, 2017.

Percy, S. (2009). Value Chain Linkages in Agribusiness Supply Chains in South Africa. EDAMBA (European Doctoral Association in Managenemnt and Business Administration) Summer school.

PICO Agriculture website. (2012). Accessed on July 2014. Available at: www.picoagriculture.com.

Roekel, J. V, Willems, S. \& Boselie, D.M. (2002). Agri-Supply Chain Management To Stimulate Cross-Border Trade in Developing Countries and Emerging Economies. World Bank Paper, Available at: www.siteresources.worldbank.org, accessed on Jan $4^{\text {th }}, 2017$.

Shabani N., Mahboobe A. \& Farzane G. (2013). The Influence of Product-related Attributes of Customers on Financial Performance. Kuwait Chapter of Arabian Journal of Business and Management Review, 2(10), 55-62. https://doi.org/10.12816/0001249

Sweeney, E. (2002). The Four Fundamentals of Supply Chain Management. National institute for transport and logistics, 5(1), 13-17.

Sweeney, E. (2007). Understanding Supply Chain Management. In Perspectives on Supply Chain Management and Logistics - Creating Competitive Organisations in the 21st Century (Sweeney, E. ed), Dublin: Blackhall Publishers, 2007, Chapter 3, 27-72.

Tiwari, S. B. (2013). Challenges and Prospects of Emerging Management and Accounting of Green Supply Chain in the Next Millennium. International Journal of scientific and research publications, 3(6), 1-12.

Trienekens J. H., Hagen, J.M., Beulens, A. J.M. \& Omta, S.W.F. (2003). Innovation Through (International) Food Supply Chain Development (case study). International Food and Agribusiness Management Review, 6(1).

Trienekens, J. H. (2011). Agricultural Value Chains in Developing Countries A Framework for Analysis. International Food and Agribusiness Management Review, 14(2), 51-82.

Trivedi, S. M. (2010). An Analysis of Financial Performance of State Road Transport Corporation in Gujarat. PH.D thesis Submitted To Department of Business Management, Saurashtra University, Rajkot, India.

Zigiaris, S. (2000). "Supply Chain Management." Report produced for EC funded project, Available at:www.adi.pt/docs/innoregio_supp_management.pdf, accessed on Jan $5^{\text {th }}, 2017$. 